\title{
GLACIOLOGICAL AND HYDROLOGICAL MAP OF THE HORNSUND FIORD AREA: 1:75000 \\ (Abstract)
}

by

\author{
J. Jania and M. Pulina
}

(Department of Karst Geomorphology, Silesian University, ul. Mielczarskiego 60, 41-200 Sosnowiec, Poland)

\section{ABSTRACT}

The problem of how to select and synthesize glaciological and hydrological information for the map of South Spitsbergen is discussed. The area of interest covers aproximately $1700 \mathrm{~km}^{2}$, but not all of it has been explored equally well so far. The map is under preparation for printing. It is one of a series of environmental maps of Hornsund at 1:75000. Geomorphology and geology have been completed already. The general objective was to reveal the spatial differentiation of glacial and hydrological phenomena in the vicinity of the Hornsund Fiord but particular interest was focused on providing synthesized information about glacial and hydrological phenomena and processes, which had been considered in the context of natural hydrological basins.

The result is a specification of the phenomena represented in the map. It had been divided into five parts: (1) elements of geomorphology, geology (lithology) and topography (basemap);

(2) features of glaciers and glacial phenomena on land;

(3) physical and chemical properties of on-land streams and glacier streams;

(4) features of marine environment and Hornsund Fiord bottom (during contruction); and

(5) general characterization and classification of phenomena occurring in hydrological basins.
The first is of a general nature. Parts two, three and four include detailed, analytical information. Part five comprises synthesized data.

The glaciers of Hornsund are specified by morphological classification, according to PSFG of the IAHS, by the position of the mean firn line and major glacier zones, and by the pattern of the ice flow-lines, along with some information on the velocity of flow. Thermal classification of the glaciers, and data on the oscillations of the glacier fronts in the 20th century are presented.

Of the Hornsund glaciers, Werenskioldbreen (approximately $27 \mathrm{~km}^{2}$ ) has been exposed in the map at 1:25000. It has roused the interest of many investigators and is amongst the best explored examples. The available set of data pertaining to this glacier consists predominantly of analytical, quantifying information, e.g. on the changes of the glacier surface altitude which occurred from 1957 to 1983 , on the net balance at selected points of the glacier, on the pattern of englacial and subglacial channels, on the discharge in glacial streams, and on the quantity and degree of mineralization and chemical content of glacial streams, etc.

The result is a coloured map which aims at representing, in a systematic and synthesized manner, contemporary phenomena and processes associated with the glaciers and the water system of the Hornsund Fiord basin.

\section{STRAIN RATES ON RUTFORD ICE STREAM, ANTARCTICA}

\section{(Abstract)}

by

N. Stephenson

(Science Applications Research, 811 Kenilworth Avenue, Riverdale, MD 20737, U.S.A.)

and C.S.M. Doake

(British Antarctic Survey, Natural Environment Research Council, High Cross, Madingley Road, Cambridge CB3 OET, England)

\section{ABSTRACT}

In a study of the Rutford Ice Stream, strain rates were measured on a transverse section. Magnitudes ranged up to $40 \times 10^{-3} \mathrm{a}^{-1}$ but were typically in the order of $3 \times 10^{-3}$ $\mathrm{a}^{-1}$ with an error of $0.1 \times 10^{-3} \mathrm{a}^{-1}$. Variations in the strain rate between adjacent stakes of $0.2 \times 10^{-3} \mathrm{a}^{-1}$ to $2 \times$ $10^{-3} \mathrm{a}^{-1}$ were matched to the thickness variations on the glacier.

For each set of three adjacent stakes, the velocity gradient components of the surface strain rate tensor were calculated by assuming that the gradients were linear over the distance between adjacent stakes. When plotted against distance across the ice stream, each strain rate component revealed different aspects of the flow field. The longitudinal strain rate was compressive, with an almost constant magnitude of $10^{-3} \mathrm{a}^{-1}$. The lateral strain rate is extensive, with an average value of $1.1 \times 10^{-3} \mathrm{a}^{-1}$ which agreed with the angle between the divergent flow lines observed on a Landsat image. Peaks in the lateral strain rate, corresponding to longitudinal bands of thicker ice, showed that these thicker bands were spreading more rapidly at the expense of thinner areas. The two velocity gradient components of the shear rate tensor also reflected differences in ice thickness. 